\title{
Research on Automatic Generation of Robotic Pathway in Typed Steel Processing
}

\author{
*Hua Guo ${ }^{1}$ and Jian-jun Wei ${ }^{2}$, \\ ${ }^{12}$ School of Mechanical Engineering, Guangxi University of Science \& Technology, Liuzhou, \\ Guangxi Province, PRC
}

\begin{abstract}
Keywords: Typed Steel Processing, Robot Off-line Programming Control, Laser Inspection, Automatic Pathway Compensation.
\end{abstract}

\begin{abstract}
In order for the robot to adapt to deformations in typed steel processing, an off-line compensation method for programming and control of robotic pathway is introduced. By installing a laser sensor on the end of robot manipulator, the geometric shapes and positions of work-piece are measured prior to executing marking and machining operation. The data obtained from the laser sensor are processed and changed into 3D coordinates of sampled points on the typed steel, which are further used to construct a simplified solid 3D model of the typed steel. Based on this 3D model, compensation parameters can obtained by calculating graphic elements with compensation rules, and thus online correction of robot pathway coordinates can be realized.
\end{abstract}

\section{Introduction}

Robot is a necessary means for ship building industry when computer integrated manufacture system, CIMS, is introduced in this field. The main challenge is how to apply robot efficiently under the conditions of small batch or single production and low work-piece dimensional precisions.

Production lines for automatic typed steel processing are introduced in recent years. This kind of machine can trace cutting torch height, but function to compensate on-line the machining graphic dimensional deviations caused by steel bending is seldom documented. In related research, robot off-line programming method for typed steel processing has been put forward. With this method, machining pathway of deformed typed steel can only be generated on the 2D plane, so production requirements is not fully met. In view of the situation of domestic shipyards steel processing, this paper, an online correction scheme of robotic typed steel machining pathway is introduced, in which data detection is based on the typed steel geometric shape and position, and machining graphic deviation caused by deformation of typed steel is calculated with Hermite interpolation method in a 3D coordinate system.

\section{Measurement of Typed Steel Geometric Shape and Position}

In the process of robot marking or cutting operation, the plasma torch must always keep a certain distance with machined surface of the typed steel. Otherwise, due to deformations of typed steel, fluctuation of the distance between plasma torch and work-piece machining surface, arc failure, not thorough cutting, low cutting surface quality or low machining graphic dimensional precision will occur. Two serious damages may be induced in severe situation: collision of plasma cutter and work-piece due to too short a distance between the plasma torch and steel processing surface; Arc break due to too long a distance between the plasma torch and steel processing surface.

Warping and deformation of typed steel are easily happened in the processes of storage, transportation, loading and unloading. When typed steel reaches the machining work table, deformations in $\mathrm{X}, \mathrm{Y}, \mathrm{Z}$ directions may be too large to guarantee the straightness of work pieces to satisfy the robotic machining requirements.

In this paper, a solution is offered: The difficulty of robot automatic machining due to typed steel deformation is solved by carrying out online robot pathway correction. The correction is based on compensations of graphic coordinate deviation and distance fluctuation between plasma torch and 
typed steel processing surface, and compensation parameters are obtained from laser sensor detected data, calculated with compensation algorithm.

The measuring principle is shown in figure 1. Before robot marking or cutting operation, laser displacement sensor is first moved by robot to a set height above the typed steel web plate, and then the laser sensor is turned on. While the robot moves from processing start point to terminal point along the section length direction (axis $\mathrm{X}$ ), variation information on axis $\mathrm{Z}$ along laser scanning pathway is collected according to certain rules by computer; then, the laser displacement sensor is moved by robot to a set height on the upper top of the plate wing. And while the robot moves from terminal point to start point along the section length direction, variation information on axis $\mathrm{Y}$ along laser scanning pathway is collected.

Space position coordinates of typed steel sample points are obtained by processing those axis $\mathrm{Z}$ and $\mathrm{Y}$ data, and those corresponding position data along the typed steel section length direction (axis $\mathrm{X}$ ). Based on space position coordinates, simplified solid 3D model of the typed steel typed steel is constructed.

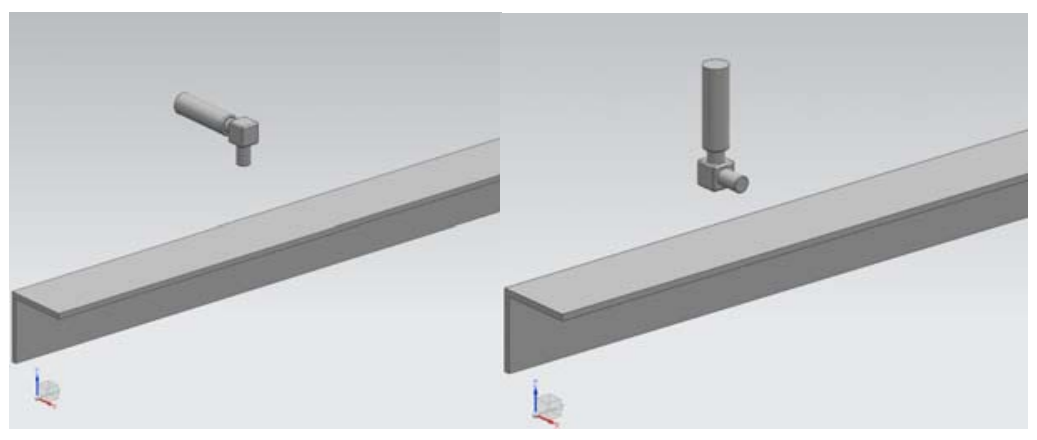

Fig.1 The principle sketch of typed steel position measuring

\section{Compensation Algorithm}

In this paper, the compensation algorithm is indicated with a punching operation on a 12 meters long bending Angle as example. Standard section is shown in figure 2 (a), deformation of the steel is shown in figure $2(b)$.

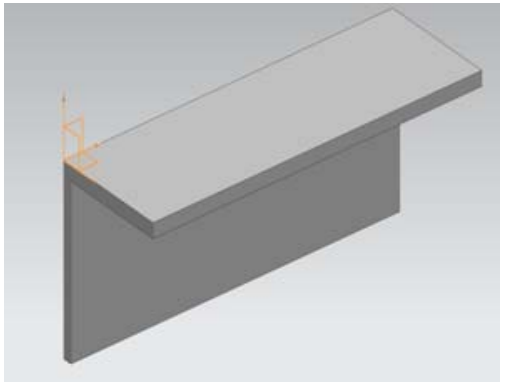

Figure 2 (a) standard steel

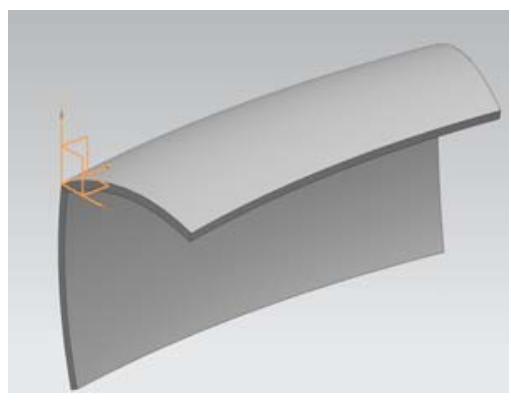

Figure 2 (b) deformation of steel

Suppose to make a hole in a certain distance on the standard steel, the hole position is $(\mathrm{X} 0, \mathrm{Y} 0, \mathrm{Z} 0)(\mathrm{X} 1, \mathrm{Y} 1, \mathrm{Z} 1)(\mathrm{X} 2, \mathrm{Y} 2, \mathrm{Z} 2)(\mathrm{X} 3, \mathrm{Y} 3, \mathrm{Z} 3)$...and to make the same hole on a deformed Angle steel, and the hole center coordinate equals to the set value on the standard typed when flattened straight. If the normal distance from hole center to the edge of the typed steel is ${ }^{L y}$, and the arc length from coordinate original point to interception point of normal line and typed steel edge is $L x$, then the position of hole center on deformed typed steel after being straightened can be identical to the CAD set value of standard typed steel. Obviously, compensation algorithm comes down to be finding 
the coordinates of corresponding points from data collected by measuring the deformed typed steel and coordinate of known point $A\left(X^{\prime}, Y^{\prime}, Z^{\prime}\right)$.

The concrete solving process is:

Transforming variation of deformation of typed steel measured by laser sensor into position information and geometrical parameters of typed steel in robot system.

With data collected from the deformed typed steel edge, and in plane (YC - ZC), (Y0, Z0), (Y1, $\mathrm{Z} 1),(\mathrm{Y} 2, \mathrm{Z} 2),(\mathrm{Y} 3, \mathrm{Z3})$, fitting curve of steel edge can be obtained with three order Hermite interpolation polynomial equation $\mathrm{H}(\mathrm{y})$. If steel edge real curve is $\mathrm{Z}=\mathrm{F}(\mathrm{y})$, the difference quotient table is as follows:

\begin{tabular}{|c|c|c|c|c|}
\hline $\mathrm{y}$ & $\mathrm{F}(\mathrm{y})$ & $\begin{array}{c}\text { First order } \\
\text { difference }\end{array}$ & $\begin{array}{c}\text { second order } \\
\text { difference }\end{array}$ & third order difference \\
\hline $\mathrm{Y} 0$ & $\mathrm{Z} 0$ & & & \\
\hline $\mathrm{Y} 1$ & $\mathrm{Z} 1$ & $\mathrm{~F}[\mathrm{Y} 0, \mathrm{Y} 1]$ & & \\
\hline $\mathrm{Y} 2$ & $\mathrm{Z} 2$ & $\mathrm{~F}[\mathrm{Y} 1, \mathrm{Y} 2]$ & $\mathrm{F}[\mathrm{Y} 0, \mathrm{Y} 1, \mathrm{Y} 2]$ & \\
\hline $\mathrm{Y} 3$ & $\mathrm{Z} 3$ & $\mathrm{~F}[\mathrm{Y} 2, \mathrm{Y} 3]$ & $\mathrm{F}[\mathrm{Y} 1, \mathrm{Y} 2, \mathrm{Y} 3]$ & $\mathrm{F}[\mathrm{Y} 0, \mathrm{Y} 1, \mathrm{Y} 2, \mathrm{Y} 3]$ \\
\hline
\end{tabular}

$\mathrm{H}(\mathrm{y})=\mathrm{Z} 0+\mathrm{F}[\mathrm{Y} 0, \mathrm{Y} 1](\mathrm{Y}-\mathrm{Y} 0)+\mathrm{F}[\mathrm{Y} 0, \mathrm{Y} 1, \mathrm{Y} 2](\mathrm{Y}-\mathrm{Y} 0)(\mathrm{Y}-\mathrm{Y} 1)+\mathrm{F}[\mathrm{Y} 0, \mathrm{Y} 1, \mathrm{Y} 2, \mathrm{Y} 3](\mathrm{Y}-\mathrm{Y} 0)(\mathrm{Y}-\mathrm{Y} 1)(\mathrm{Y}-\mathrm{Y} 2$ )

Solution: $\mathrm{Z}=\mathrm{H}(\mathrm{y})$ function equation

The curve length equation can be obtained: $L y=\int_{1}^{1} \sqrt{1+\left[H^{\prime}(y)\right]^{2}} d y$

Where ${ }^{L y}$ known, ${ }^{L y}$ is the distance from $\left(0, Y^{\prime}, 0\right)$ to point $\mathrm{A}$ in axis $\mathrm{X}$, a1=0, which derives from the $\mathrm{b} 1$, the b1 into $\mathrm{Z}=\mathrm{H}(\mathrm{y}), \mathrm{Z} 1=\mathrm{H}(\mathrm{b} 1)$.

(1)In plane (XC-ZC), (X0, Z0) $(\mathrm{X} 1, \mathrm{Z} 1)(\mathrm{X} 2, \mathrm{Z} 2)(\mathrm{X} 3, \mathrm{Z} 3)$, with three order Hermite interpolation polynomial equation for $\mathrm{H}(\mathrm{x})$, fitting curve of steel edge can be fund. The real curve of the steel edge is set to $\mathrm{Z}=\mathrm{F}(\mathrm{x})$, the difference is as follows

\begin{tabular}{|c|c|c|c|c|}
\hline $\mathrm{x}$ & $\mathrm{F}(\mathrm{x})$ & $\begin{array}{c}\text { first order } \\
\text { difference }\end{array}$ & $\begin{array}{c}\text { second order } \\
\text { difference }\end{array}$ & third order difference \\
\hline $\mathrm{X} 0$ & $\mathrm{Z} 0$ & & & \\
\hline $\mathrm{X} 1$ & $\mathrm{Z} 1$ & $\mathrm{~F}[\mathrm{X} 0, \mathrm{X} 1]$ & & \\
\hline $\mathrm{X} 2$ & $\mathrm{Z} 2$ & $\mathrm{~F}[\mathrm{X} 1, \mathrm{X} 2]$ & $\mathrm{F}[\mathrm{X} 0, \mathrm{X} 1, \mathrm{X} 2]$ & \\
\hline $\mathrm{X} 3$ & $\mathrm{Z} 3$ & $\mathrm{~F}[\mathrm{X} 2, \mathrm{X} 3]$ & $\mathrm{F}[\mathrm{X} 1, \mathrm{X} 2, \mathrm{X} 3]$ & $\mathrm{F}[\mathrm{X} 0, \mathrm{X} 1, \mathrm{X} 2, \mathrm{X} 3]$ \\
\hline
\end{tabular}

$\mathrm{H}(\mathrm{x})=\mathrm{Z} 0+\mathrm{F}[\mathrm{X} 0, \mathrm{X} 1](\mathrm{X}-\mathrm{X} 0)+\mathrm{F}[\mathrm{X} 0, \mathrm{X} 1, \mathrm{X} 2](\mathrm{X}-\mathrm{X} 0)(\mathrm{X}-\mathrm{X} 1)+\mathrm{F}[\mathrm{X} 0, \mathrm{X} 1, \mathrm{X} 2, \mathrm{X} 3](\mathrm{X}-\mathrm{X} 0)(\mathrm{X}-\mathrm{X} 1)(\mathrm{X}-\mathrm{X} 2)$

Solution: $\mathrm{Z}=\mathrm{H}(\mathrm{x})$ function equation.

The curve length equation can be obtained: $L x=\int_{2}^{2} \sqrt{1+\left[H^{\prime}(x)\right]^{2}} d x$

Where $L x$ is known, $L x$ is arc length from $(0,0)$ to point A along axis $X, L x=X^{\prime}$, a2 $=0, \mathrm{~b} 2$ can be calculated, with $\mathrm{b} 2$ brought into $\mathrm{Z}=\mathrm{H}(\mathrm{x})$, then, $\mathrm{Z} 2=\mathrm{H}$ (b2).

The coordinate of point $A$ in the coordinate system of standard type steel coordinate system is (b1,b2, Z3), in which, Z3=Z1+Z2.

\section{Data Communication between Industrial Computer and Robot}

Typed steel processing graphics include straight line, circle or arc and other basic graphics. Each kind of graphics can be represented by a set of parameters and graphic elements, for example, a line can be represented by two endpoints; a circle can be represented by a center and a radius, etc. Typed steel machining graphic library can be established by CAD software, and basic procedural sub-module of processing graphic can be established in executive robotic programs through off-line programming. When the typed steel is put on the work table, processing task files are invoked from 
file server, or are directly created by inputting processing graphic element coordinates from screen window. Once the robotic typed steel processing system is activated, the system can conduct measuring, marking and cutting automatically according to set procedures.

\section{Conclusions}

The technology of automatic generation of robotic pathway has been tested on typed steel machining operation. With off-line programming control, laser measurement of the shape and position of the typed steel, compensation calculation of the coordinate deviation of the machining pattern, real time data communication between computer and robot controller, and online correction of robot pathway, industrial robot has been successfully applied in marking, cutting operations in ship manufacturing. The results of the tests show that the system can machine typed steel quite precisely even when lateral deflection of typed steel reaches $\pm 30 \mathrm{~mm}$, and deflection in height direction reaches $\pm 10 \mathrm{~mm}$. During the operation, typed steel is freely placed on work table without fixation and positioning. By adopting the new technology, the requirement of flatness of the typed steel is greatly reduced. Typed steel straightening equipment is no longer a necessity, which leads to lower manufacturing cost. The automatic compensation technology for robot machining pathway, proposed in this paper, can not only facilitate the robot application in ship shipbuilding industry, but also can be applied to material machining in the fields of bridge and architecture construction, vehicle and construction machinery manufacturing, etc.

\section{Acknowledgement}

This research was financially supported by Innovation Project of Guangxi Graduare Education 20 15; and Guangxi key Scientific and Technological Project \# 1598013-12.

\section{References}

[1] Zhou Xin-min, Development of automatic machining system for typed steel [J], Chinese and foreign ship technology 1996, 1.

[2] Ding Min-jian, Robot technology in shipyard production environment [J], Chinese and foreign ship technology 1997,4.

[3] Wang Hong-jie, Yao Shun, Ding Guo-qing. Development of robot flexible manufacturing system for shipbuilding material [R]. The tenth welding annual seminar, 2001.10.

[4] Wang H J,et al.Robot auto-marking and auto-cutting of shipbuilding Panels based on a compensation algorithm [J].Industrial Robot, 2001,28(5):425- 433.

[5] Wang Feng, Yonghe, Jiao Guotai.Analysis method of position and orientation error of industrial robot under multi-factor influence [J]. Journal of Applied Science and engineering 2004, 12 (4): 435 $\sim 442$.

[6] Yong Jie, Zheng Ji-gui, Yang Xue-you. Method for robot calibration with laser tracker machine [J].Chinese Journal of mechanical engineering, 2007, 43 (9): $195 \sim 200$. 